\title{
ECONOMIC REGULATION BUSINESS OF CONSTRUCTION ORGANIZATIONS
}

\section{ЕКОНОМІЧНЕ РЕГУЛЮВАННЯ БІЗНЕСУ БУ ДІВЕЛЬНИХ ПІДПРИЕМСТВ}



Yatsenko Ihor V., Candidate of Economic Science (Ph.D.), Associate Professor, National Transport University, Associate Professor of Economics Department, tel. +380442803016, Ukraine, 01010, Kyiv, M. Omelianovycha-Pavlenka Str., 1, office 313 .

https://orcid.org/0000-0002-3562-613X

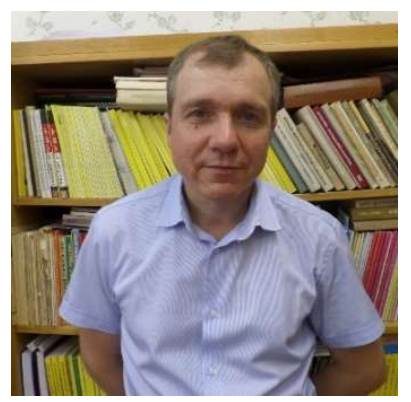

Kaskiv Volodymyr I., Candidate of Engineering Science (Ph.D.), Associate Professor, National Transport University, Associate Professor of Department of Transport Construction and Property Management, e-mail: vi_kas@ukr.net, tel. +380504458544, Ukraine, 01010, Kyiv, M. Omelianovycha-Pavlenka Str., 1, office 138.

https://orcid.org/0000-0002-8074-6798

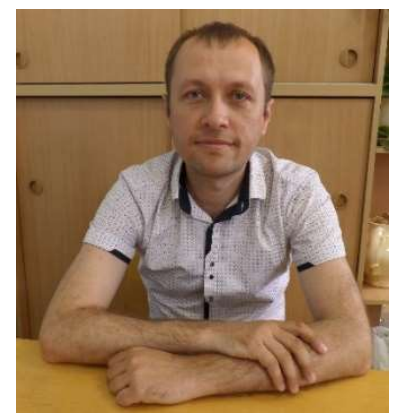

Chechuha Oleksand S., Candidate of Engineering Science (Ph.D.), Associate Professor, National Transport University, Associate Professor of Department of Transport Construction and Property Management, e-mail: chechuga77@gmail.com, tel.+380662019442,Ukraine,01010, Kyiv, M. Omelianovycha-Pavlenka Str., 1, office 138.

https://orcid.org/0000-0003-1643-6354

Summary. The thesis presents methodological approaches to diagnosis and restructuring the system of economic regulation business processes of construction organizations, aimed to stabilize their economic development. It was suggested a new definition of the term «business process of construction organization» and performed the decomposition of business processes in construction. It was determined main components of management of construction organizations, which allow improving their structure and consolidating all processes with strategically goals. It was improved the outsourcing mechanism to optimize financial processes and flows of subcontract construction organizations under condition of constrains on resources and deadlines on the construction of residential buildings designed and optimal measures of pre-payment. A new approach for the management of financial flows by means of fuzzy sets. Found out typical failings in administration of business processes in «effective» and «ineffective» of construction organizations to restructure their activity. It was conducted determinative factor analysis of profitability of operating activity in construction industry and worked out measures to improve the situation. Worked out the quantitative characteristics of key business processes, which allow defining the size of the advance payment of a customer to optimal level. 


\section{ЕКОНОМІКА; ОБЛІК І ОПОДАТКУВАННЯ; МЕНЕДЖМЕНТ; МАРКЕТИНГ; ПІДПРИСМНИЦТВО, ТОРГІВЛЯ ТА БІРЖОВА ДІЯЛЬНІСТЬ}

Keywords: business process of construction organizations, optimization financial flows, characteristics of key business processes, the size of pre-planning payment, outsourcing in construction.

Formulation of the problem. Economic development of modern enterprises as complex self-organizing open systems, characterized by such features as: increasing dynamism of processes, multiplicity, sensitivity to changes in the characteristics of the environment, increased nonlinearity and feedback, variation of characteristics so valued. Such factors of the conditions of operation of economic entities require a radical increase in the efficiency of adaptive management, aimed at regulating business processes of the enterprise.

The formation of a modern civilized market and socially oriented market relations is determined by the course and management of business processes of a particular enterprise. Since construction companies are the formative form of the investment and economic potential of the national economy, the effectiveness of their business processes should be a matter for both academics and practitioners, not only at the level of the individual enterprise, but also at the national level. The dynamic nature of the competitive environment in which construction companies operate is forcing them to constantly find new, more effective methods of managing adaptation and economic development mechanisms with the obligatory requirement to increase the competitiveness of products or services.

Analysis of recent publications. Many of the scientific works are devoted to problems of increasing the efficiency of enterprise management, among which the works of such Ukrainian and others scientists as A.V. Busyhina, D.M. Gvishiani, V.H. Herasimchuka, A.Yu. Denysova, S.A. Zhdanova, V.I. Knorringa, V.M. Kolpakova, V.S. Kulibanova, V.S. Ponomarenka, A.H. Porshneva and others. With regard to improving the management of construction companies, then here should bring the works of such authors: A.Ye. Achkasova, A.V. Druzhynina, V.F. Zalunina, O.S. Ivanilova, L.M. Kozara, Yu.P. Panibratova, B.V. Prykina, I.S. Stepanova, O.A. Tuhaia, V.I. Torcatiuka, R.B. Tiana, S.A. Ushatskoho, L.M. Chystova and other well-known scientists in this field. The essence and essential characteristics of business processes of enterprises in the process of creating a new value is reflected in the writings of foreign scholars such as E. Deming, V. Shuhart, M. Robson, F. Ullah, J. Becker. Among others researchers, the methodology of business process management deserves attention to the development of E.V. Novoselova V.I. Romanchina, A.S. Tarapanova, H.A. Kharlamova, V.H. Eliferova, S. Riba, I. Kremliovoii, O.V. Malysheva, M.Z. Svitkina, A. Kuriana and P. Serenkova.

The results of numerous studies allowed to develop effective economic and organizational tools for local adaptation of business entities to market conditions, but there are still no effective mechanisms for integrated management of the entire complex of business processes of construction enterprises. This leads to an imbalance of development capital investment across the economy, excessive sensitivity to external disturbances and catastrophic instability of construction companies, regardless of their size, area of economic activity and types of business entity. In this connection, there is an urgent need to study methods and develop new technologies for process management of construction enterprises, which led to the choice of subject, subject and subject of research, as well as the definition of its goals and objectives.

The purpose and tasks of the study. The purpose of the work is to develop a theoretical concept and methodical tools for diagnosing and synthesizing the system of economic regulation of business processes of construction enterprises, aimed at stabilizing their economic development.

Systematization of the reasons complicating the widespread introduction of process-oriented management by enterprises of the investment and construction complex, has revealed the main factors of destabilization of entrepreneurial activity in construction, namely: the lack of a clearly formulated policy and strategic goals in the field of process management of quality; insufficient level of professionalism of quality management personnel; insufficient financing of construction and installation works and investments in the latest 
technologies and materials; ignorance of the requirements of the ISO 9001 to the development and implementation of processes and their integration into the quality management system.

The conducted studies have provided the basis for identifying the main obstacles to business process management in creating value in construction and the mechanism for their elimination through a purposeful restructuring of the management system at the industry. It was established that the discreteness in time of the through business process of a construction enterprise is largely due to the discrepancy of the results of the output of the previous process with the criteria for the inputs of the next process. This non-coordination of business processes becomes more severely affected if it is detected in the event of a collision of the outputs of the subcontractor's business processes with the inputs of the business processes of the general contractor, since the break of the chain in this case will be more significant and its elimination will be characterized by higher costs of each party, and therefore and greater losses in the value of the final product. It is necessary to define the concept of the "business process of a construction company", namely: it is an integral chain of coordinated operating links, which, with the help of technology and organizations, transform the input resources into a result (initial, intermediate or final products), the consumer value of which for the client exceeds the cost spent on his resources. As a result of the analysis of scientific approaches to the essence of process management and its place in the system of quality management of construction products, the decomposition of the business processes of the construction company was performed. The main process for construction contractors and for most general contractors of enterprises is a set of processes of "construction site" of general construction (installation and laying) and start-up and adjustment, the output of which is intermediate or final construction products. The security processes, first of all, include the logistic and economic-legal processes that provide the resource inputs of the main process, as well as project-organizational processes, which not only provide, but also optimize inputs of the main process by distributing resources between work, and accompany the process itself, promoting the quality of products, rational use of all kinds of resources and reducing their unproductive costs. Accompanying security processes are the financial-fiscal and part of the administrative processes, as the creation of construction products is characterized by a long and productive cycle that exceeds the length of periods of payment of basic taxes and the formation and delivery of regular financial statements.

In our opinion, repair, restoration and marketing processes should be included in the business processes of development of a construction company, which in scientific researches are defined as auxiliary processes of transformation. Marketing processes related to the study of demand for intermediate and final construction products, the search for new customers, the expansion of the market niche of the enterprise, the formation of its portfolio of orders, ultimately contribute to the long-term stage of accelerated development of the construction company and ensure its adaptation to the requirements of the competitive environment.

Summarizing the scientific and technical provisions gives grounds to assert that the "weakness" of the chain of business processes of a construction company, the elimination of which does not exclude outsourcing, is determined by isolating the integral blocks of processes and assessing the volume of their resources in comparison with the consumer value of the output. An in-depth analysis of the DBN D.1.1-1-2000 and other normative acts, which defined the methodology for calculating prices for construction products, made it possible to draw a conclusion on the strict regulation of the economic parameters of the auxiliary and security business processes that are accounted for in such items of expenses as generic and Administrative expenses. The cost of auxiliary and supportive business processes imposes an additional constraint on their labor intensity and labor costs for the relevant category of employees, since the corresponding amounts also are directly proportional to the complexity of the main business processes of the construction site. Such circumstances require construction companies, especially subcontractors, to rationalize their internal organizational structure, reduce internal transaction costs, as excessive deployment of control apparatus, unreasonable economic feasibility processes and business operations increase the cost of construction products. 
To identify typical deficiencies in the process approach to managing construction companies, we will conduct a deterministic factor analysis of the profitability of operating activities in the whole industry. As a result, the following causes of complications of process management in construction were identified:

1. Inefficiencies in the use of hired workers, as they do not ensure the proper quality of work performed.

2. Ineffective management of the levers of the economic mechanism, because excessive labor reproduction costs do not increase payroll, and the level of prices for final construction products established by builders is high, compared to its value for consumers, which results in low profitability of construction.

3. The high material construction of the construction is caused by a high share of the cost of materials and logistics costs associated with the timely provision of inputs of major business processes.

A common for all enterprises of the "non-performing" group is the tendency of inefficiency to administer the through business process, which consists of an imperfect management system both in the construction process and in the processes accompanying it. Loss of solvency is due to the inability of such enterprises to generate sufficient income from their core business, since the cost of outlets through the process often exceeds the value of outputs for customers. Thus, changes in the management system for a "non-performing" group of companies should be more extensive and involve participants in both the main and auxiliary processes. More successful companies have gaps in the administration of auxiliary business processes, and for unprofitable joint stock companies there is a need to improve management not only auxiliary, but also the main building business process.

In the conditions of destabilization of the construction services market, when the customer, as a carrier of demand, plays a decisive role, the opportunity to receive income from their activities will be exclusively productive enterprises, the quality of outputs of the through process which is acceptable to the customer. Such enterprises should have an "acceptable" assessment of the administration of business processes, that is, the value of $B_{\text {gen }} \geq 1.05$. Using correlation-regression analysis, a tight correlation between the dependent variable and the indicator of return on wages was established, that is, the value of net income from the sale in the calculation of $1 \mathrm{UAH}$ labor costs. This result is due to the decisive role of the labor factor in ensuring the continuity of the business processes chain to create the ultimate consumer value. The magnitude of the salary of employees, which among the sample of construction enterprises has a log-normal distribution, was included in the logit regression equation, the value of which is proposed to be considered as an indicator of the effectiveness of management of the main and security business processes.

According to the results of the component analysis, it is established that the growth of debit indebtedness, the cost of realized CIW negatively affects the formation of the main factors, that is, there are signs of weaknesses in management.

The analysis of the main factors has statistically confirmed the results of the diagnosis of the effectiveness of the administration of the through business process and the conclusion on the difference of priority tasks of improving the economic mechanisms of enterprises with different levels of effectiveness.

Enterprises that managed to withstand the macroeconomic crisis, relatively better administer the basic processes of construction production, but require better management of financial and fiscal security processes. The main reason for the inefficient, loss-making activity of construction enterprises is due to the low efficiency of management of the main building site processes and their logistical support.

The optimization task consists in determining the maximum of the target function - the share of material costs in the estimated cost of the construction business process, while respecting the set of restrictions that are determined by the technical and economic parameters of general construction works, provided by the technologies of construction of high-rise multi-section brick residential houses.

For general construction works: $0.865-0.975 x_{1}-2.365 x_{2}+0.819 x_{3} \rightarrow \max$.

For plumbing works: $0.931-0.999 x_{1}-2.44 x_{2}+0.516 x_{3} \rightarrow \max$.

Independent variables included in the optimization tasks are governed by the following restrictions: 
0.01 ;

1. The target function can not be a negative number, and variables can not be less than $1 \%: x_{1} x_{2} x_{3} \geq$

2. Taking into account the diversity of possible design decisions and technologies for their implementation in the construction of objects, in the role of the second constraint, it was accepted that each of the investigated structural elements of the estimated cost of the average level, that is, the average arithmetic mean of the percentages, was accepted. Thus, for general construction works $x_{1} \leq 4.85 \%, x_{2} \leq 12.70 \%, x_{3} \leq 16.55 \%$, and for sanitary works $x_{1} \leq 4.82 \%, x_{2} \leq 12.34 \%, x_{3} \leq 13.99 \%$.

3. The value of the target function should not exceed the optimal value equal to the value of the free constant of the regression equation, $y \leq 0.865$ for general construction works and $y \leq 0.931$ for sanitary-technical.

4. Since a significant amount of construction works is carried out manually and is labor-intensive, the share of labor costs should not be lower than the average value of the sample: for general construction work: $1-y-x_{1}-x_{2} \leq 0.1712$, for sanitary-technical works: $1-y-x_{i}-x_{2}<0.1746$.

The solution of the proposed tasks with the help of MS Exel allowed to determine the optimal size of the share of material costs in the estimated cost of construction, and hence the size of the down payment for construction outsourcing, which is respectively:

- for general construction works $-72.1 \%(y=0.721)$. In this case, the size of other structural components of the estimate are as follows: the cost of operation of machines and mechanisms $\left(x_{1}\right)-1 \%$, total production costs $\left(x_{2}\right)-9.78 \%$, salaries of the main workers $-17.12 \%$.

- for sanitary-technical works $-74.53 \%(y=0.7453)$. At the same time, the sizes of other structural components of the estimate are as follows: the cost of operation of machines and mechanisms $\left(x_{1}\right)-1.05 \%$, total production costs $\left(x_{2}\right)-7.51 \%$, salaries of the main workers $-16.91 \%$.

Given the results of the solution of tasks it is not expedient to give outsourcing high-tech, capitalintensive work, which uses such machines and mechanisms that require high-skilled workers and labor-intensive construction processes. If, however, subcontractors carry out work with less than the optimal share of material costs, it is advisable to reduce the amount of the down payment for such work. As an option, the solution to the problem of economic regulation of business processes of construction enterprises is proposed to manage financial flows through a fuzzy logic approach. When designing a system of regulation of financial processes of construction enterprises, a three-element set of input linguistic variables (LV) with gaussian, zlike and s-like membership functions was given (Table 1). They allow us to calculate the degree of confidence in the affiliation of each of the terms LV to any value of the variable of economic characteristics within a universal set.

In the used Larsen algorithm, dephasing is performed by the center of gravity method, that is, the clear value of the output variable corresponds to the abscissa of the center of gravity of the area of the curvilinear figure obtained at the aggregation stage. In order to improve the interaction of the participants in the construction process, it is expedient to document the components of the system of fuzzy conclusion documented in the contracts for the implementation of the CIW. In particular, in the "Obligations of the parties" and "Payment terms" sections it is expedient to indicate the terms of bonus and fines of the executor, which will affect not only the amount of the advance payment, but also the contract price of the work. The quantitative characteristics of the main business process, which correspond to the "threshold for the preservation of acceptable value" in the proposed system, are:

- the quality of work execution is $94.5 \%$, that is, the proportion of shortcomings that require immediate elimination should not exceed $5.5 \%$ of the completed CIW volume;

- the term of work execution is 1,03 , therefore the delay can not be higher than $3 \%$ of the time scheduled by the project of works execution (PWE) and the calendar schedule;

- not less than $95 \%$ of the content of the estimate documentation should be unmistakable. 
Table 1 - Parameters of membership functions used when applying a fuzzy-logical approach

Таблиця 1 - Параметри функцій належності, що використані при застосуванні нечітко-логічного підходу

\begin{tabular}{|c|c|c|}
\hline $\begin{array}{l}\text { Linguistic varia- } \\
\text { ble }\end{array}$ & Term name & Functional view \\
\hline & & Input variables \\
\hline $\begin{array}{l}\text { The quality of } \\
\text { work, the qual- } \\
\text { ity of the esti- } \\
\text { mated documen- } \\
\text { tation }\end{array}$ & is unsatisfactory & 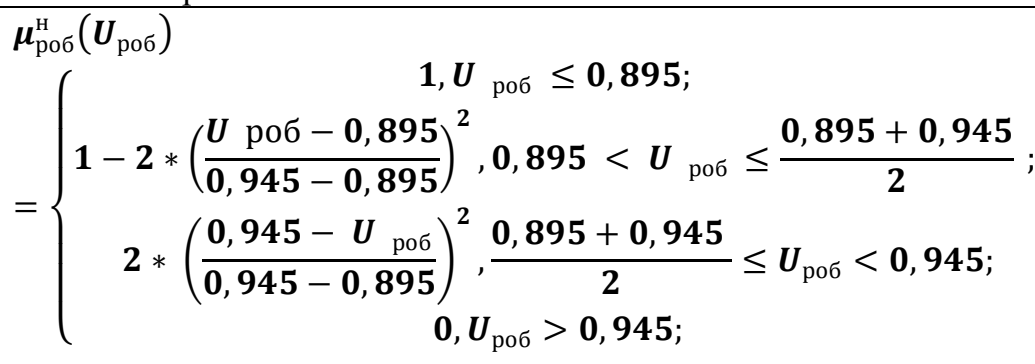 \\
\hline $\begin{array}{l}\text { Linguistic varia- } \\
\text { ble }\end{array}$ & Term name & Functional view \\
\hline & satisfactory & $\boldsymbol{\mu}_{\mathrm{poб}\left(U_{\mathrm{p} о б}\right)}^{3}=\exp \left(-\frac{1}{\mathbf{2}} *\left(\frac{U_{\mathrm{poб}}-\mathbf{0}, \mathbf{9 5}}{\mathbf{0 , 1 8}}\right)^{2}\right)$ \\
\hline & flawless & 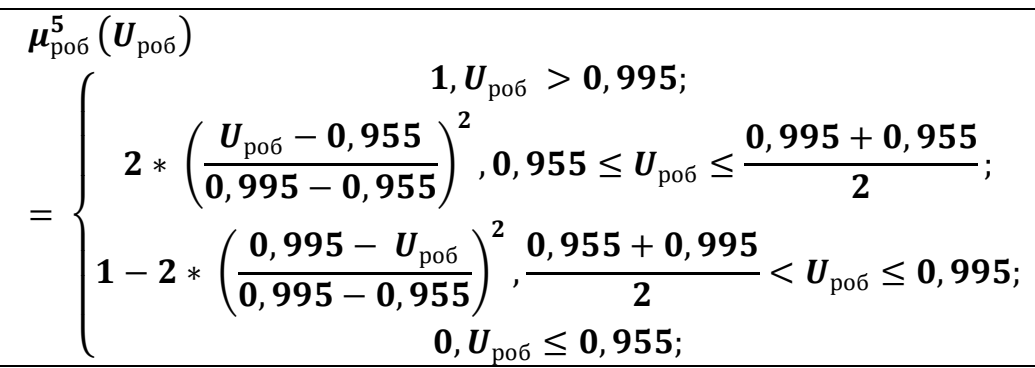 \\
\hline \multirow{3}{*}{$\begin{array}{l}\text { The term of } \\
\text { work }\end{array}$} & $\begin{array}{l}\text { execution is } \\
\text { ahead of the } \\
\text { schedule }\end{array}$ & 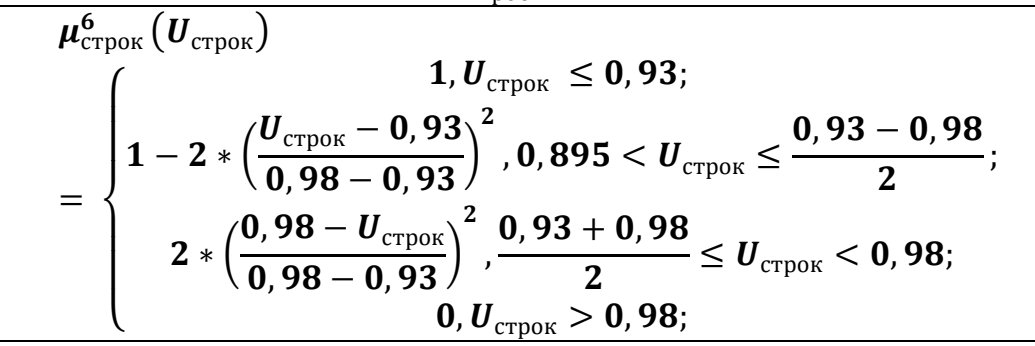 \\
\hline & on time & $\boldsymbol{\mu}_{\text {строк }}^{\mathrm{c}}\left(\boldsymbol{U}_{\text {строк }}\right)=\exp \left(-\frac{\mathbf{1}}{\mathbf{2}} *\left(\frac{\boldsymbol{U}_{\text {строк }}-\mathbf{1}}{\mathbf{0 , 0 4}}\right)^{2}\right)$ \\
\hline & With delay & 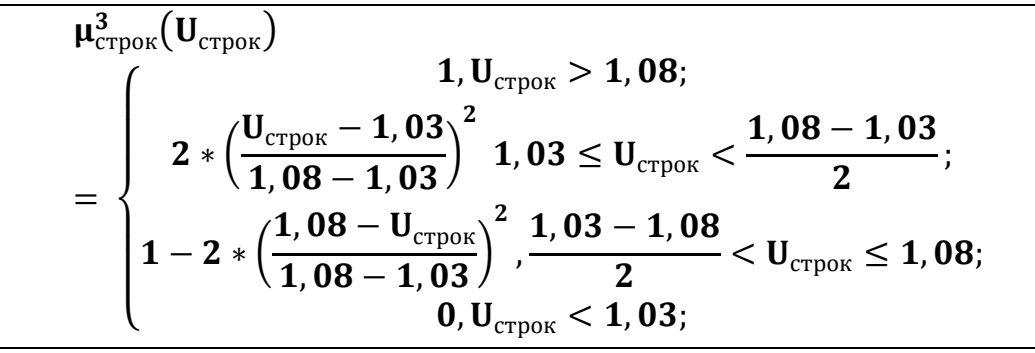 \\
\hline \multirow{4}{*}{$\begin{array}{l}\text { The amount of } \\
\text { advance pay- } \\
\text { ment }\end{array}$} & \multicolumn{2}{|r|}{ Output variables } \\
\hline & Fines & $\boldsymbol{\mu}_{\text {аванс }}^{\text {штраф }}\left(\boldsymbol{U}_{\text {допл }}\right)=\exp \left(-\frac{\mathbf{1}}{\mathbf{2}} *\left(\frac{\boldsymbol{U}_{\text {допл }}+\mathbf{0 , 2}}{\mathbf{0 , 0 5}}\right)^{\mathbf{2}}\right)$ \\
\hline & $\begin{array}{c}\text { Economically } \\
\text { optimal }\end{array}$ & $\boldsymbol{\mu}_{\text {аванс }}^{\text {опт }}\left(\mathbf{U}_{\text {допл }}\right)=\exp \left(-\frac{\mathbf{1}}{\mathbf{2}} *\left(\frac{\mathbf{U}_{\text {допл }}-\mathbf{0}}{\mathbf{0 , 0 4}}\right)^{\mathbf{2}}\right)$ \\
\hline & bonus & $\boldsymbol{\mu}_{\text {аванс }}^{\mathrm{\Pi}}\left(\mathbf{U}_{\text {допл }}\right)=\exp \left(-\frac{1}{\mathbf{2}} *\left(\frac{\mathbf{U}_{\text {допл }}-\mathbf{0 , 2}}{\mathbf{0 , 0 5}}\right)^{2}\right)$ \\
\hline
\end{tabular}






Determination of the sensitivity of the specific weight of direct and general construction costs to the complexity of technologies that are used by constructing linear regressive levels

Determination of the economic structure of the "reference" construction business process by compiling and solving an optimization task of minimizing material and transport logistics costs

$\downarrow$

Select a process for outsourcing by criteria:

the share of material and transport and logistics costs the ratio of labor costs for labor-

builders and labor costs taken into account as part of total production costs the share of expenses for the operation of machines and mechanisms minimum administrative and other conditional expenses

$\downarrow$

Analysis of previous subcontractor experience (as a potential outsourcer) by cost criteria:

the quality of the performed construction and installation work timeliness of execution of volumes of commissioned works (in accordance with contractual ob- the quality of the preparation of the estimated, financial and other supporting documentation

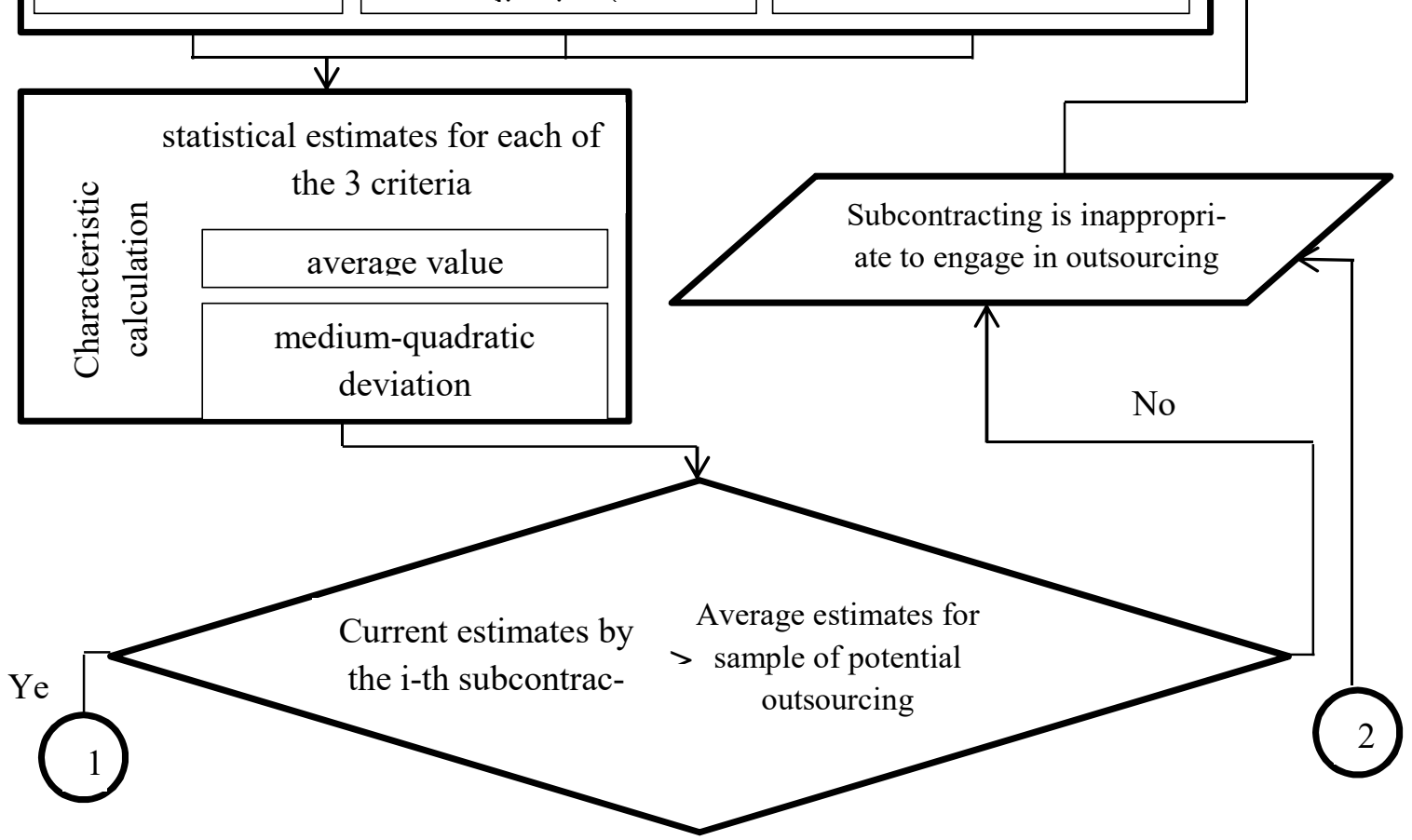






Subcontractor-outsourcer selection for the fulfillment of the process according to the criteria: the quality and timeliness of the implementation of the CIW and the quality of the preparation of the estimates and fi-



Calculation using the fuzzy-model of the expediency of additional financial incentives for the subcontractor-outsourcer during the final calculation for the performed work

\section{End}

Figure 1 - The algorithm for improving the system of economic regulation of business processes at construction enterprises

Рисунок 1 - Алгоритм удосконалення системи економічного регулювання бізнес-процесів на будівельних підприємствах 
In order to increase the amount of prepayment by $5 \%$ and it is right to demand from the customer strict observance of contractual obligations in the part of the schedule of payments for executed works, the "threshold of preservation of value" should meet the following criteria:

- The quality of work execution is $97.5 \%$, that is, the percentage of shortcomings that require immediate removal, must not exceed $2.5 \%$ of the executed volume of CIW;

- the term of work execution is 0.95 , hence the advance can not be less than $5 \%$ of the time scheduled by the calendar schedule;

- not less than $93.5 \%$ of the content of the estimate documentation should be unmistakable.

In order to increase the efficiency of business process administration of subcontractors, an algorithm for economic regulation of business processes was developed (Fig. 1). The fuzzy conclusion system is central to the management technology of the through business process of construction enterprises, since its use is foreseen at the final stages (No.9 - No.12) of the algorithm. The implementation of this management technology can accelerate the output of the construction industry from the economic crisis, reducing the ineffective losses of limited cash resources and the volume of poor-quality construction products.

Conclusions. The paper formulates and solves the actual scientific and applied task of effective economic instruments for the regulation of business processes of construction enterprises. In the course of the study, a number of new approaches have been proposed to clarify the essence of the concept of "business processes" in relation to the management of construction production, the classification of business processes, the outputs of which ensure the creation of the value of a construction product, the diagnosis of the efficiency of managing processes at the micro and macro levels, diagnostics of objective needs in the restructuring of business processes of a construction company, optimization of financial flows in the outsourcing of major construction business processes, the use of optimization results under uncertain economic environment. The results obtained are a significant contribution to the development of the concept and economic tools for diagnosing and synthesizing the system of economic regulation of business processes of construction enterprises, aimed at stabilizing their economic development.

1. Having analyzed the conceptual approaches of process-oriented management, the essence of the concept of "business processes of a construction enterprise" has been clarified, namely: "This is an integral chain of coordinated functioning links, which, by means of technology and organization of production, transform the input resources into the result (initial, intermediate or final products), whose consumer value exceeds the cost of the client's resources for the client". This definition more fully reflects the economic expediency of implementing process-oriented management in construction companies.

2. It is established that it is impossible to determine a universal list of business processes for construction enterprises. The reengineering of business processes of a construction company involves management regulation of such a set of supporting processes of management improvement and development of companies, the outputs of which ensure satisfaction of the economic interests of consumers of construction products.

3 . Based on the proposed system approach to the division of business processes of construction enterprises by their place in the system of quality management of construction products, it has been established that the main process for construction enterprises is a set of processes of a "construction site" of general construction and commissioning, the output of which is intermediate or final construction products . A number of security processes contribute to a steady flow and create the necessary value for consumers of the outputs of the main process.

4. In order to ensure adaptation of the economic system of a construction company to an unstable macroeconomic environment during the crisis and recession, the set of auxiliary business processes and, accordingly, the tasks of process management of construction enterprises, are proposed to be classified according to the following groups: logistic, technical and technological development, administrative and controlling, marketing and financial and fiscal. 
5. The method of assessing the effectiveness of economic management of business processes and determining the need for changes in business process management mechanisms is theoretically substantiated and developed, which, unlike existing ones, involves comparing the actual and standard dynamics of economic indicators, as well as analyzing the net income in terms of every hryvnia labor costs. The essence of the proposed method is to determine the efficiency of business process administration using logit regression with one independent variable - payload. It is established that the marginal values of wages, which indicate the potential of a construction company to obtain a positive financial result due to the effective administration of the through business process, should exceed 8.28 ... 9.41 UAH.

6 . The conducted research of the main factors of the through business process of construction enterprises has statistically confirmed the results of diagnostics of the efficiency of administration of the through business process and allowed to generalize the differences in the priority tasks of improving the economic mechanisms of enterprises with different levels of performance:

- enterprises that managed to withstand the macroeconomic crisis, relatively better administer the basic processes of construction production, but require better management of financial and fiscal security processes;

- the main reason for the ineffective, loss-making activity of construction enterprises is due to low efficiency of management of the main processes of the construction site and their logistical support. Negative consequences of such deformations through the chain of value creation complicate the activity of construction enterprises even under favorable conditions of the macroeconomic environment.

\section{References}

1. Bondarenko Ye.V. Vstup do teorii upravlinnia biznes-protsesamy budivelnykh pidpryiemstv // Ekonomika ta derzhava, 2016. № 10. S. 58-60.

2. Bondarenko Ye.V., Sorokina L.V., Hoiko A.F. Upravlinnia biznes-protsesamy yak vazhlyvyi chynnyk pidvyshchennia yakosti produktsii budivnytstva // Shliakhy pidvyshchennia efektyvnosti budivnytstva $\mathrm{v}$ umovakh formuvannia rynkovykh vidnosyn, 2013. Vyp. 18. S. 150-158.

3. Bondarenko Ye.V. Osnovni pidkhody do vymiru rezultatyvnosti protsesnoho upravlinnia budivelnym pidpryiemstvom // Budivelne vyrobnytstvo, 2016. № 49. S. 97-101.

4. Hoiko A.F. Stratehichne upravlinnia lohistychnymy biznes-protsesamy budivelnykh pidpryiemstv: priorytetni zadachi ta shliakhy yikh vyrishennia // Nauchno-tekhnycheskyi sbornyk. Kommunalnoe khoziaistvo horodov, 2015. № 87. S. 172-178.

5. Hoiko A.F., Sorokina L.V.rytmizatsiia upravlinnia biznes-protsesamy budivelnykh pidpryiemstv v umovakh ekonomichnoi kryzy // Aktualni problemy ekonomiky, 2013. № 8 (98). S. 58-66.

6. Sorokina L.V., Hoiko A.F.Metodyka ekspres-diahonostyky rezultatyvnosti upravlinnia biznesprotsesamy diiuchykh pidpryiemstv // Ekonomichnyi prostir, 2016. № 39. S. 277-286. 


\section{ЕКОНОМІЧНЕ РЕГУЛЮВАННЯ БІЗНЕСУ БУДІВЕЛЬНИХ ПІДПРИЄМСТВ}

Яценко Ігор Володимирович, кандидат економічних наук, доцент, Національний транспортний університет, доцент кафедри економіки, тел. +380442803016 , Україна, 01010, м. Київ, вул. М. Омеляновича-Павленка, 1, к. 313. https://orcid.org/0000-0002-3562-613X.

Каськів Володимир Іванович, кандидат технічних наук, доцент, Національний транспортний університет, доцент кафедри транспортного будівництва та управління майном e-mail: vi_kas@ukr.net, тел. +380504458544, Україна, 01010, м. Київ, вул. М. Омеляновича-Павленка, 1, к. 138.

https://orcid.org/0000-0002-8074-6798

Чечуга Олександ Сергійович, кандидат технічних наук, доцент, Національний транспортний університет, доцент кафедри транспортного будівництва та управління майном e-mail: chechuga77@gmail.com, тел. +380662019442 , Україна, 01010, м. Київ, вул. М. Омеляновича-Павленка, 1, к. 138. https://orcid.org/0000-0002-8074-6798

Анотація. У роботі досліджено методологічні підходи до діагностики та реструктуризації системи економічного регулювання бізнес-процесів будівельних підприємств, спрямованих на стабілізацію їх економічного розвитку. Запропоновано власне визначення поняття «бізнес-процесу будівельного підприємства» та виконано декомпозицію бізнес-процесів у будівництві. Визначено головні компоненти управління будівельними підприємствами, які дозволяють поліпшити їх оргструктуру та узгодити процеси нижчого порядку із головними цілями. Вдосконалено аутсорсинговий механізм оптимізації фінансових процесів і потоків підрядних будівельних підприємств в умовах жорстких обмежень на ресурси та терміни виконання робіт по зведенню житлових будівель, а також розраховано оптимальний розмір авансового платежу. Запропоновано новий підхід щодо управління фінансовими потоками при аутсорсингу за допомогою засобів теорії нечітких множин. Виявлено типові недоліки в адмініструванні бізнес-процесів «результативних» і «нерезультативних» будівельних підприємств, на підставі яких визначено основні напрямки і рівень поглиблення процесної реструктуризації будівельних підприємств. Проведено детермінантний факторний аналіз рентабельності операційної діяльності в цілому по галузі, внаслідок якого були виділені основні причини ускладнень процесного управління у будівництві. Встановлено кількісні характеристики основного бізнес-процесу, які відповідають «порогу збереження прийнятної цінності» і дозволяють підвищити розмір авансового платежу Замовника порівняно із економічно оптимальним рівнем.

Ключові слова: бізнес-процес будівельного підприємства, оптимізація фінансових потоків, характеристики основного бізнес-процесу, розмір авансового платежу, аутсорсинг у будівництві.

\section{Перелік посилань}

1. Бондаренко Є.В. Вступ до теорії управління бізнес-процесами будівельних підприємств // Економіка та держава, 2016. № 10. С. 58-60.

2. Бондаренко Є.В., Сорокіна Л.В., Гойко А.Ф. Управління бізнес-процесами як важливий чинник підвищення якості продукції будівництва // Шляхи підвищення ефективності будівництва в умовах формування ринкових відносин, 2013. Вип. 18. С. 150-158.

3. Бондаренко Є.В. Основні підходи до виміру результативності процесного управління будівельним підприємством // Будівельне виробництво, 2016. № 49. С. 97-101.

4. Гойко А.Ф. Стратегічне управління логістичними бізнес-процесами будівельних підприємств: пріоритетні задачі та шляхи їх вирішення // Научно-технический сборник. Коммунальное хозяйство городов, 2015. № 87. С. 172-178.

5. Гойко А.Ф., Сорокіна Л.В.ритмізація управління бізнес-процесами будівельних підприємств в умовах економічної кризи // Актуальні проблеми економіки, 2013. № 8 (98). С. 58-66.

6. Сорокіна Л.В., Гойко А.Ф.Методика експрес-діагоностики результативності управління бізнес-процесами діючих підприємств // Економічний простір, 2016. № 39. С. 277-286. 